\title{
University of Florida/IFAS Ornamental Plant Improvement Program: Three Caladium, Two Gerbera, and Thirteen Lisianthus Cultivars Released in $2005^{1}$
}

\section{Zhanao Deng and Brent K. Harbaugh ${ }^{2}$}

Florida is the second largest producer of floricultural crops in the United States. Flowers and plants produced by the Florida floriculture industry are marketed to domestic as well as international customers. One of the major thrusting forces of the industry is frequent introduction of new cultivars. New cultivars with new or improved floricultural characteristics, improved production and/or landscape performance, disease resistance, or stress tolerance keep Florida growers competitive in domestic and international markets. New cultivars with these attributes also result in better container or garden performance for consumers in Florida, in other parts of the United States, or in other countries. As part of the University of Florida/IFAS ornamental plant improvement program, the Gulf Coast Research and Education Center's program focuses on developing new cultivars for several major floricultural crops including caladium, gerbera, and lisianthus. Each of these crops generates a multi-million dollar farm gate value in Florida. This breeding program released three new caladium, two gerbera, and thirteen lisianthus cultivars in 2005.

\section{Caladium}

Caladiums are used as potted plants or in container gardening and landscape decoration. Their bright color display, excellent tolerance to summer heat and rains, and strong resistance to diseases or insect pests have made them popular and easy to grow and enjoy. Commercial caladium plants are grown from tubers. The Florida caladium industry, centered in the Lake Placid-Sebring-Avon area, provides over $95 \%$ of the tubers used in the world. The University of Florida/IFAS caladium breeding program began in 1976 (Wilfret, 1988). The breeding objectives were to develop new cultivars that could produce a high yield of good tubers with multiple branches, require no or optional de-eyeing practices, sprout early, develop numerous leaves with sturdy petioles and a good display of bright vibrant colors. Recently, new breeding objectives have been added to the program and the priority has been on improving caladium's resistance to Fusarium tuber rot and to Pythium root rot. Three new cultivars were released in 2005 , and are being propagated by a number of caladium growers.

1. This document is ENH1051, one of a series of the Environmental Horticulture Department, Florida Cooperative Extension Service, Institute of Food and Agricultural Sciences, University of Florida. Original publication date April, 2007. Visit the EDIS Web Site at http://edis.ifas.ufl.edu.

2. Zhanao Deng, assistance professor; and Brent K. Harbaugh, professor, Gulf Coast Research and Education Center, Florida Cooperative Extension Service, IFAS, University of Florida, Gainesville, FL 32611.

The Institute of Food and Agricultural Sciences (IFAS) is an Equal Opportunity Institution authorized to provide research, educational information and other services only to individuals and institutions that function with non-discrimination with respect to race, creed, color, religion, age, disability, sex, sexual orientation, marital status, national origin, political opinions or affiliations. U.S. Department of Agriculture, Cooperative Extension Service, University of Florida, IFAS, Florida A. \& M. University Cooperative Extension Program, and Boards of County Commissioners Cooperating. Larry Arrington, Dean 
'Garden White' caladium (Deng and Harbaugh, 2006b) is a white fancy-leaved cultivar. White fancy caladiums have been very popular. 'Aaron', 'Candidum', 'Candidum Junior', and 'White Christmas' are the four major cultivars currently on the market, and they account for over $90 \%$ of all the white cultivars grown. Compared to these cultivars, 'Garden White' is more vigorous and taller, has larger leaves, and has greater tolerance to sun burn. Thus it is ideal for use in sunny landscapes or large containers. In addition, its tuber production was improved. For example, in 2003 and 2004 field trials, 'Garden White' was 30\% to $80 \%$ more productive than 'Aaron', 'Candidum', 'Candidum Junior', and 'White Christmas'.

'Firecracker Red' caladium (Deng and Harbaugh, 2006a) is a red fancy-leaved cultivar. 'Frieda Hemple' and 'Postman Joyner' have been two of the primary red fancy cultivars commercially produced. Leaves of these cultivars are intense red, but their tubers are susceptible to Fusarium tuber rot. Developing improved red cultivars has been one of the main objectives in this breeding program since its beginning. 'Firecracker Red' produces many large leaves with intense red color and grows well in sunny landscapes and large containers. 'Firecracker Red' has a higher tuber production value (30\% to $40 \%$ greater) than 'Frieda Hemple' and 'Postman Joyner'.

'Summer Rose' caladium (Deng and Harbaugh, 2006c) was intended to replace 'Rosebud'.

'Rosebud' is a pink fancy cultivar and well liked for its unique pattern of bright pink color. However, tuber production in 'Rosebud' has been rather costly due to a disease called Grassy Tuber. Growers have to manage this disorder by manual rouging of symptomatic plants. Costs of rouging and reduced yield make production of 'Rosebud' difficult. 'Summer Rose' is similar in color and container performance to 'Rosebud', but it has a higher tuber yield and performs better than 'Rosebud' does. In addition, its petioles are red purple at the leaf attachment and gradually darken to brown at the petiole base.

\section{Gerbera}

Gerbera has been very popular in Europe, and its popularity has been increasing in the U.S. For example, the sales volume of cut gerberas in California is only second to that of cut roses. This increase in the popularity of gerberas is also seen in flower gardens, landscapes and large patio containers. Yet, breeding of gerberas for this use has just received attention from seed companies. We believe that a good garden gerbera plant needs to have adequate plant vigor and size, appropriate flower heights, disease resistance, and stress tolerance. The goal of our gerbera breeding program is to develop cultivars with novel flower colors, resistance to powdery mildew, upright sturdy peduncles, and continuous flowering in the garden.

'UF Multi-flora Peach' and 'UF Multi-flora Pink Frost' gerbera plants (Deng and Harbaugh, 2006d) have novel flower colors and an intermediate level of powdery mildew resistance. Plants display multiple flowers and buds resulting in plants with as much color as plants with larger but fewer flowers. Both cultivars also are very vigorous and produce large plants with a continuous supply of flowers.

\section{Lisianthus}

Lisianthus is native to the plain states in the U.S., but pioneering breeding of this flower was done in Japan. It was introduced as a "new" cutflower back to the U.S. market in the early 1980s. Production of this crop in Florida and other subtropical U.S. areas was difficult due to its uneven flowering habit caused by a complex interaction among genetics, high temperatures, and short photoperiods. A lisianthus breeding program was initiated in 1985 at the University of Florida's Gulf Coast Research and Education Center. The emphasis has been on development of heat tolerant cultivars with a basal branching habit and suitable heights for use as pot or bedding plants. Heat tolerance is especially critical for year-round production of lisianthus in Florida and other regions where high temperatures are present during the production season. When seedlings are exposed to temperatures above $25^{\circ} \mathrm{C}$, many cultivars will rosette and not flower, or flower only erratically. Sources of heat 
tolerance were identified in lisianthus in 1992. These sources have served the basis for the lisianthus breeding.

Basal branching is another trait emphasized in the breeding program. Multiple branches developed from basal nodes make pot lisianthus plants much fuller and of greater color impact, and boost garden performance when lisianthus are used as bedding plants. Two F1 hybrid cultivars, 'Maurine Blue' and 'Florida Blue', were released in 1995 (Harbaugh and Scott, 1996; Harbaugh et al., 1996). They represented the first of two cultivar series (Maurine and Florida) whose seedlings could be grown at $28^{\circ} \mathrm{C}$ to $31^{\circ} \mathrm{C}$ without rosetting and could flower normally. More colors were added in subsequent years, and now the Maurine series and the Florida series consist of eight colors and six colors, respectively. The Maurine cultivars were intended for production of flowering pot plants with use of growth retardants or use as bouquet cut flowers without use of growth retardants. The Florida series, on the other hand, was intended for use as bedding plants.

Two new lisianthus series were released in 2005: UF Savanna (Harbaugh and Deng, 2006b) and the UF Double Joy (Harbaugh and Deng, 2006a). Similar to the Maurine and the Florida series, the UF Savanna series is single-flowered, but the plant height of this series is intermediate between the Maurine cultivar group and the Florida cultivar group. This height will reduce the use of growth retardants, and thus be very beneficial for greenhouse production of flowering potted lisianthus. There are eight colors in this series: blue, pink, white, silver, blue rim, pink rim, blue frost, and pink frost. 'UF Savanna Blue Frost' and 'UF Savanna Pink Frost' are the first of their kinds in the pot type lisianthus.

The 'UF Double Joy' cultivar group was developed in response to growers' and consumers' need of double flowered lisanthus. Although single flowers are still the most popular flower type in the European and the Japanese market, double flowering lisianthus have become very popular in the U.S. market in the recent years. Currently $80 \%$ of the cut lisianthus sold in the U.S. are double flowering. There has been a need of double flowered pot or bedding plant type lisianthus. Transferring the double flowering trait from a cut flower type to a pot type was not easy, but the most challenging part of developing double flowered pot lisianthus has been developing male and female fertile inbreds that are required for production of F1 hybrids. Many double flowered inbreds tended to develop abnormally with nearly sterile anthers or ovaries. This difficulty was overcome through rigorous and continuous selection of numerous inbreds. This series now consist of five colors.

When the seedlings of the UF Double Joy or the UF Savanna cultivars were exposed to $28^{\circ} \mathrm{C}$ to $31^{\circ} \mathrm{C}$ for five weeks, $100 \%$ of their plants flowered normally. In contrast, for many commercial cultivars, only 14 to $70 \%$ of their plants flowered after exposure to high temperatures.

\section{Literature Cited}

Deng, Z. and B.K. Harbaugh. 2006a. 'Firecracker Red' - A red fancy-leaved caladium for sunny landscapes and containers. HortScience 41:471-473.

Deng, Z. and B.K. Harbaugh. 2006b. 'Garden White' - A large white fancy-leaved caladium for sunny landscapes and large containers. HortScience 41:840-842.

Deng, Z. and B.K. Harbaugh. 2006c. 'Summer Rose' - A fancy-leaved caladium for containers and landscapes. HortScience 41:468-470.

Deng, Z. and B.K. Harbaugh. 2006d. 'UF Multi-flora Peach' and 'UF Multi-flora Pink Frost': Multi-flora gerbera cultivars for landscapes and large pots. HortScience 41:843-845.

Harbaugh, B.K. and Z. Deng. 2006a. 'UF Double Joy' cultivar group - five colors of double-flowering and heat-tolerant lisianthus for potted plants. HortScience 41:846-849.

Harbaugh, B.K. and Z. Deng. 2006b. 'UF Savanna' cultivar group - eight colors of heat-tolerant lisianthus for potted plants. HortScience 41:850-854. 
Harbaugh, B.K. and J.W. Scott. 1996. 'Maurine

Blue' lisianthus [Eustoma grandiflorum (Raf.)

Shinn.]. HortScience 31:1055-1056.

Harbaugh, B.K., J.W. Scott, and D.B. Rubino.

1996. 'Florida Blue' semi-dewarf lisianthus

[Eustoma grandiflorum (Raf.) Shinn.]. HortScience

31:1057-1058.

Wilfret, G.J. 1988. 'Florida Cardinal', A red caladium for forcing. Fla. Agric. Exp. Station

Circular S-351.

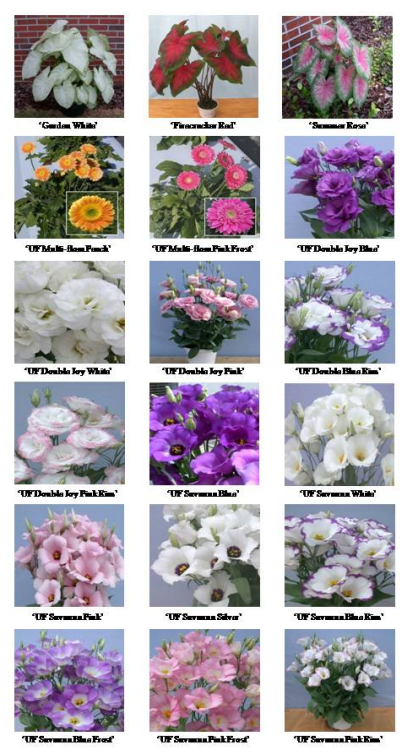

Figure 1. 